Collection: Cost Action E29 Meeting 2008 - Istanbul (Turkey)

Future Monitoring and Research Needs for Forest Ecosystems

Guest Editor: Marcus Schaub (WSL, Birmensdorf, $\mathrm{CH}$ )

\title{
Future monitoring and research needs for forest ecosystems in a changing environment: an introduction
}

\author{
Schaub M \\ In order to identify future monitoring and research needs, a COST Strategic \\ workshop on the role of "Forest ecosystems in a changing environment" as- \\ sembled nearly 180 scientists from 30 countries in Istanbul on 11-13 March \\ 2008. The workshop specifically tackled the fields of climate change and \\ forests, ozone, atmospheric deposition and critical loads, biodiversity, as well \\ as quality assurance in forest monitoring.
}

Keywords: Climate change, Ozone, Atmospheric depositions, Critical loads

Over the last 50 years, humans have changed the Earth's ecosystems more rapidly and extensively than in any comparable period of time in human history (Millenium Ecosystem Assessment 2005). The global annual average nitrogen deposition over land is expected to increase by a factor of about 2.5 , leading to an increased eutrophication and acidification. For present-day conditions, Lamarque et al. (2005) suggest that the deposition over land ranges between 25 and 40 $\operatorname{Tg}(\mathrm{N}) /$ year. Over forests, the deposition is expected to increase globally from $10 \operatorname{Tg}(\mathrm{N})$ year to $20 \operatorname{Tg}(\mathrm{N}) /$ year by 2100 . Tropospheric ozone $\left(\mathrm{O}_{3}\right)$ is a global air pollution problem and an important greenhouse gas. Although not a new issue, ground level $\mathrm{O}_{3}$ remains one of the most pervasive of the global air pollutants with impacts on human health, food production and the environment. Between the late $19^{\text {th }}$ century and 1980 , concentrations of background $\mathrm{O}_{3}$ in the Northern Hemisphere mid-latitudes doubled to about 30-35 $\mathrm{ppb}$ and have since increased by a further 5 $\mathrm{ppb}$ to $35-40 \mathrm{ppb}$. Future $\mathrm{O}_{3}$ concentrations strongly depend on global emissions and

Swiss Federal Research Institute WSL, Zürcherstrasse 111, CH-8903 Birmensdorf, Switzerland

@, Marcus Schaub (marcus.schaub@wsl.ch)

Received: Jan 09, 2009 - Accepted: Jan 30, 2009

Citation: Schaub M, 2009. Future monitoring and research needs for forest ecosystems in a changing environment: an introduction. iForest 2: 54-55 [online: 2009-01-29] URL: http://www.sisef.it/iforest/show.php? id $=488$ global warming. However, even if emissions are reduced and background $\mathrm{O}_{3}$ declines, it is expected that there will be an increase in the frequency of high pollution days due to the changes in weather expected under future climate change. In Europe there is likely to be an increase in the frequency of summer droughts, heat-wave events, and associated high $\mathrm{O}_{3}$ episodes (Royal Society 2008). Global greenhouse gas emissions have grown since pre-industrial times with an increase of $70 \%$ between 1970 and 2004. Depending on the model and scenarios used, projected global average surface warming is expected to increase by 0.6 to $4.0^{\circ} \mathrm{C}$ at 2090 2099 relative to $1980-1999$. However, northern Hemisphere temperatures during the second half of the $20^{\text {th }}$ century were very likely higher than during any other 50-year period in the last 500 years and likely the highest in at least the past 1300 years (IPCC 2007).

These factors, indicating a rapidly changing environment, are threatening and damaging forest ecosystems. Increasing concentrations of tropospheric $\mathrm{O}_{3}$ may reduce the photosynthetic capacity of trees resulting in a reduced growth rate and carbon allocation (Novak et al. 2007). The increase in deposition of nitrogen to forest soils is threatening the integrity and functioning of forest ecosystems. Predicted changes in average temperature and precipitation will strongly affect ecological conditions of forests and their plant communities. In addition, extreme weather events like storms, high temperatures, and long lasting droughts are predicted to occur more often in the future, putting forests at risk.

The issue of air pollution, climate change and forest health problems is characterized by multi-causality with different strengths of association. The linkages between air pollutant exposures and plant ecosystem responses have complex inter relationships as their impacts depend on the environmental pollutants and conditions being considered while influenced by factors such as genetic constitution, age, nutrition and adaptation (Schaub \& Paoletti 2007). The impacts on forest ecosystems have been traditionally treated separately for air pollution and climate change. However, the combined effects may significantly differ from a sum of their parts. Simultaneous addressing of the air pollution and climate change effects on forests is an opportunity for capturing synergies in future monitoring and research (Bytnerowicz et al. 2007).

In order to identify future monitoring and research needs, a COST Strategic workshop on the role of "Forest ecosystems in a changing environment" assembled nearly $180 \mathrm{sci}$ entists from 30 countries in Istanbul from 11-13 March 2008. In plenary and parallel sessions, the workshop specifically tackled the fields of climate change and forests, ozone, atmospheric deposition and critical loads, biodiversity, as well as quality assurance in forest monitoring.

A part of the presentations during these sessions has been included in this special issue of iForest - Biogeosciences and Foresty and summarizes key studies on potential and actual impacts of air pollution and climate change on forests. The themes are centered around the following topics of global importance: linking critical thresholds and loads (Augustin 2009, Wuyts et al. 2009) to forest condition, tree reactions to air pollution and climate change (Beck 2009, Serafinaviciute \& Stakenas 2009), assessment of biodiversity (Feest \& Spanos 2009, Granke et al. 2009), long-term monitoring of deposition and integrated effects (Lorenz \& Granke 2009, Lundin 2009), modelling carbon budgets, deposition loads and ozone fluxes (Jochheim et al. 2009, Staelens et al. 2009, Tuovinen 2009), monitoring policy and instruments (Johannessen 2009, Requardt et al. 2009, Logan et al. 2009), and quality assurance and control activities for ecological monitoring (Sase et al. 2009).

There is evidence that forest ecosystems will be exposed to even more rapid changes of environmental conditions in the future. The combined effects of global warming and air pollution are complex and may differ from a sum of separate effects. In order to measure these, and to assess the environmental risk and its consequences on the ecosystem functioning such as carbon sink and protection of soil and water, a well-established and continuous forest long-term monitoring is crucial.

In the early 1980's, large scale forest de- 
cline and deterioration led to the Convention on Long-range Transboundary Air Pollution (CLRTAP, Geneva 1979) which was crucial for launching forest monitoring within the frame work of the International Co-operative Programme on the Assessment and Monitoring of Air Pollution on Forests. Today, increasing awareness of the rapidly changing environment should lead to more integrated and intensified monitoring and research efforts enabling reliable quantification of risk assessment of global change and air pollution.

\section{References}

Augustin S (2009). Linking critical thresholds for acidity to forest condition by using element contents in tree rings: consequences for the development of an integrated ecosystem assessment. iForest 2: 51-53. - doi: 10.3832/ifor0487-002

Beck W (2009). Growth patterns of forest stands the response towards pollutants and climatic impact. iForest 2: 4-6. - doi: 10.3832/ifor0472-002

Bytnerowicz A, Omasa K, Paoletti E (2007). Integrated effects of air pollution and climate change on forests: A northern hemisphere perspective. Environmental Pollution 147: 438-445. - doi: 10.1016/j.envpol.2006.08.028

Feest A, Spanos K (2009). An approach to measuring biodiversity and its use in analysing the effect of nitrogen deposition on woodland butterfly populations in the Netherlands. iForest 2: 46-48. - doi: 10.3832/ifor0487-002

Granke O, Kenter B, Kriebitzsch WU, Köhl M, Köhler R, Olschofsky K (2009). Biodiversity assessment in forests - from genetic diversity to landscape diversity. iForest 2: 1-3. - doi: 10.3832/ifor0474-002

IPCC (2007). Summary for policymakers. In: "Climate change 2007: mitigation". Contribution of working group III to the fourth assessment report of the Intergovernmental Panel on Climate Change (Metz B, Davidson OR, Bosch PR, Dave $\mathrm{R}$, Meyer LA eds). Cambridge University Press,
Cambridge (UK) and New York (USA).

Jochheim H, Puhlmann M, Beese F, Berthold D, Einert P, Kallweit R, Konopatzky A, Meesenburg H, Meiwes K-J, Raspe S, Schulte-Bisping $\mathrm{H}$, Schulz C (2009). Modelling the carbon budget of intensive forest monitoring sites in Germany using the simulation model BIOME-BGC. iForest 2: 7-10. - doi: 10.3832/ifor0475-002

Johannessen T (2009). Clean air policy under the UNECE Convention on long-range transboundary air pollution: how are monitoring results "translated" to policy action. iForest 2: 49-50. doi: 10.3832/ifor0476-002

Lamarque J-F, Kiehl JT, Brasseur GP, Butler T, Cameron-Smith P, Collins WD, Collins WJ, Granier C, Hauglustaine D, Hess PG, Holland EA, Horowitz L, Lawrence MG, McKenna D, Merilees P, Prather MJ, Rasch PJ, Rotman D, Shindell D, Thornton P (2005). Assessing future nitrogen deposition and carbon cycle feedback using a multimodel approach: Analysis of nitrogen deposition, J. Geophys. Res. 110: D19303 doi: 10.1029/2005JD005825

Logan JA, Macfarlane WW, Willcox L (2009). Effective monitoring as a basis for adaptive management: a case history of mountain pine beetle in Greater Yellowstone Ecosystem whitebark pine. iForest 2: 19-22. - doi: 10.3832/ifor0477002

Lorenz M, Granke O (2009). Deposition measurements and critical loads calculations: monitoring data, results and perspective. iForest 2: 11-14. doi: 10.3832/ifor0478-002

Lundin L (2009). Hydrology, element budgets, acidification, nutrient $\mathrm{N}$ in a climate change perspective for the northern forest region. iForest 2 : 23-25. - doi: 10.3832/ifor0479-002

Millenium Ecosystem Assessment (2005). Global Assessment Reports. Web Site. [online] URL: http://www.millenniumassessment.org/en/Global.aspx

Novak K, Cherubini P, Saurer M, Fuhrer J, Skelly JM, Kräuchi N, Schaub M (2007). Ozone air pollution effects on tree-ring growth, delta(13)C, visible foliar injury and leaf gas exchange in three ozone-sensitive woody plant species. Tree Physiology 27: 941-949. [online] URL: http://www.ncbi.nlm.nih.gov/pubmed/17403646 Requardt A, Schuck A, Köhl M (2009). Means of combating forest dieback - EU support for maintaining forest health and vitality. iForest 2: 38 42. - doi: 10.3832/ifor0480-002

Royal Society (2008). Ground-level ozone in the $21^{\text {st }}$ century: future trends, impacts and policy implications. RS Policy document 15/08. The Royal Society, London, UK.

Sase H, Nakayama S, Leong CP, Kamisako M, Luangjame J, Garivait H, Visaratana T, Kietvuttinon B, Ueda H (2009). QA/QC activities and ecological monitoring in the Acid Deposition Monitoring Network in East Asia (EANET). iForest 2: 26-29. - doi: 10.3832/ifor0481-002

Schaub M, Paoletti E (2007). Introductory remarks to the special section for the 2005 IUFRO World Congress, Brisbane, Australia. In: \&\#8220;Air pollution and climate change: a global overview of the effects on forest vegetation (Schaub $\mathrm{M}$, Paoletti E eds). Environmental Pollution 147: 429. - doi: 10.1016/j.envpol.2006.08.040

Serafinaviciute B, Stakenas V (2009). Ozone fumigation effects on the morphology and biomass of Norway spruce (Picea abies L.) saplings. iForest 2: 15-18. - doi: 10.3832/ifor0483-002

Staelens J, Neirynck J, Genouw G, Roskams P (2009). Dynamic modelling of target loads of acidifying deposition for forest ecosystems in Flanders (Belgium). iForest 2: 30-33. - doi: 10.3832/ifor0484-002

Tuovinen J-P (2009). Ozone flux modelling for risk assessment: status and research needs. iForest 2: 34-37. - doi: 10.3832/ifor0485-002

Wuyts K, De Schrijver A, Verheyen K (2009). The importance of forest type when incorporating forest edge deposition in the evaluation of critical load exceedance. iForest 2: 43-45. - doi: 10.3832/ifor0486-002 